\title{
Eco-Epidemiology and Control of Waterborne Gastroenteritis: A Review
}

\author{
Siddique $\mathrm{F}^{1 *}$, Iqbal $\mathrm{A}^{2}$, Sabir $\mathrm{H}^{3}$, Manzoor $\mathrm{M}^{3}$, Hussain $\mathrm{I}^{3}$, Mahmood $\mathrm{MS}^{3}$ and Ahmad SI
}

${ }^{1}$ Institute of Microbiology, University of Agriculture, Faisalabad-38040, Pakistan

${ }^{2}$ Riphah College of Veterinary Sciences, Lahore, Pakistan

${ }^{3}$ University of Animal and Veterinary Science, Lahore, Pakistan

\begin{abstract}
Viral and bacterial pathogens appear to be the causative agents of water-borne gastroenteritis globally. Waterborne gastroenteritis is the primary cause of loss of productivity and morbidity in developed and underdeveloped nations. Lack of extensive epidemiological surveillance and data analysis of viral and bacterial waterborne gastroenteritis is a major hindrance in the control of this disease. The burden of gastroenteritis is highest in the children and immunocompromised persons as compared to the elderly population. Essentially, Rotavirus, Norovirus, Pestivirus, Escherichia coli, Listeria monocytogenese, Yersinia pestis, Clostridium difficile, Vibrio cholerae, Aeromonashydrophila are primary causative organisms of waterborne gastroenteritis globally. This review highlights the current knowledge of waterborne pathogens and their significance, epidemiological factors like worldwide prevalence, hosts, causative agents, associated risk factors, clinical signs and symptoms, conventional as well as molecular diagnostic tools to combat the disease and recent approaches to effective treatments and new innovative methods of controlling these infectious agents that cause gastroenteritis will be discussed.
\end{abstract}

Keywords: Control; Listeria monocytogenese; Vibrio cholera; Norovirus; Treatments

\section{Introduction}

Gastroenteritis is a devastating disease particularly in children less than five year of age globally. In 1825, for the first time the term gastroenteritis was used to describe this symptom. Previously it was confusing with cholera morbus or griping of the guts. In medical language, gastroenteritis or stomach flu or gastric flu is an inflammation of the stomach and the small intestine. Centuries ago, at the time of Hippocrates, it was assumed that weaning and weather of infants were associated with gastroenteritis. It was thought that both teething and hot climate contribute to the development of infantile gastroenteritis.

Food-borne pathogens have a major role in the spread of this disease. Abdominal pain, diarrhea, vomiting and dehydration are the cardinal signs of gastroenteritis. The percentage of mortality and morbidity is higher in under developed countries as compared to developed countries. This may be due to the prevalence of high level of sanitation and the accessibility of healthcare in developed countries [1]. It has been reported that more than 1.1 billion children of $\leq 5$ years of age were more susceptible to this disease. Gastroenteritis infections annually result in 7.6 million deaths in South Asian countries including Pakistan and a number of the Eastern Mediterranean countries. From 2008 to 2015, one million deaths have been recorded in Pakistan alone which reflects the severity and primarily significance of this notorious infection [2]. Outbreaks of gastroenteritis primarily depends upon a variety of risk factors among children and adults such as contaminated pond water which was used for washing, bathing, drinking and cooking purposes without boiling [3], use of smokeless tobacco [4], malnutrition, excessive use of antibiotics as well as psychological factors such as anxiety, depression [5] and immunocompromised patients [6].

\section{Epidemiology of gastroenteritis}

Prevalence: Gastroenteritis is a global disease present around the world but most prevalent in under developed countries where hygienic and sanitary conditions are very poor. Annually, five billion children are affected globally resulting in the death of nearly 1.4 million. Bacteria particularly involved with gastroenteritis are mainly Escherichia coli, Vibrio cholerae, Salmonella typhimurium, Shigelladysenteriae,
Campylobacter jejuni while among viruses rotavirus and norovirus are the primary causes of gastroenteritis [7]. The epidemics of this disease have been reported from many countries including Germany [8], USA [9-11], Colorado [12], Switzerland [13], France [14], Netherland, Japan, Sweden, UK, Korea [15], Philippines [16], China [17,18], Pakistan [2,19], India [20], Bangladesh [21], Iran, [22], Saudi Arabia [23,24].

Possible host and transmission: There are different pathognomic signs of gastroenteritis such as vomiting (three or more episodes or less than three episodes in 24 hours), diarrhea (three or more episodes in 24 hours or less than three episodes) and two or more other symptoms including stomach ache, nausea, abdominal cramps, blood or mucus in stool, fever [1]. Children especially those less than five year of age and adults of over forty year of age, irrational users of antibiotics and immune-compromised hosts are most susceptible [12]. Thus children and elderly people are more prone to gastroenteritis attacks. This may be because of developmental changes in immune response, comorbid conditions, gastrointestinal physiology and heavy use of medications and associated with aging. The transmission of this disease through fecal-oral route [25].

Possible causative agents: Gastroenteritis is a nastiest disease caused by many bacterial species like highly toxigenic E. coli O157:H7 strain, Salmonella typhimurium, Shigella dysenteriae, Staphylococcus aureus, Clostridium difficile, Listeria monocytogenese, Bacillus cereus, Vibrio cholerae, Yersinia pestis [26], Aeromonas spp. and Campylobacter jejuni, Brachyspira species [27] and viral species including rotavirus, astrovirus, adenovirus, pestivirus, norovirus [28-31]. Viruses particularly rotaviruses, caliciviruses, astroviruses and adenoviruses are

*Corresonding author: Siddique $\mathrm{F}$, Institute of Microbiology, University of Agriculture, Faisalabad-38040, Pakistan, Tel: 0092-333-6629016; E-mail: drfaisal1674@yahoo.com

Received May 01, 2015; Accepted July 03, 2015; Published July 10, 2015

Citation: Siddique F, Iqbal A, Sabir H, Manzoor M, Hussain I, et al. (2015) EcoEpidemiology and Control of Waterborne Gastroenteritis: A Review. J Food Process Technol 6: 477. doi:10.4172/2157-7110.1000477

Copyright: ( $) 2015$ Siddique F, et al. This is an open-access article distributed under the terms of the Creative Commons Attribution License, which permits unrestricted use, distribution, and reproduction in any medium, provided the original author and source are credited. 
the main cause of the gastroenteritis in children. Among them, group A rotaviruses are the leading cause of severe acute gastroenteritis in infants and children globally, causing an estimated 500,000 to 600,000 deaths annually. Two to three years aged children are more susceptible and associated with acute diarrhea [32].

Associated determinants or other risk factors: Poor nutritional status, infants and aged people with low level of immunity, contaminated water source, gender, drinking, bathing, washing and recreational [33], use of contaminated water, sewerage and waste disposal problems [34], poor shelter and housing arrangements, overcrowding, food source, animal handling, domestic animals, fly and insect control are major risk factors of this disease [35].

Climate change factors: Wet and dry seasons play an important role in the spread of gastroenteritis which is associated with the time of epidemics e.g. Astrovirus gastroenteritis prevalence was found to be high in winter months $(51.72 \%)$ as well lowest incidence were recorded in summer months (6.89\%) [36]. Seventy nine percent epidemics of norovirus occurred during winter season, which showed strong winter seasonality as compared with bacterial gastroenteritis e.g. Shigella spp. were most frequent during summer months [37].

Miscellaneous factors: A number of miscellaneous factors such as foreign travel, camping, public vomiting episode, heavy use of antibiotic, baby care, ingestion of raw, spoiled and new marine products, family illnesses and homosexuality have also been associated with gastroenteritis in human beings $[27,38]$.

\section{Clinical picture and diagnosis}

Watery diarrhea, vomiting, stomach pain, nausea, cramping and associated headaches and dry mouth and skin, dehydration are major signs and symptoms of this disease. History of the patients such as duration of illness, fever, vomiting, abdominal pain, dehydration, travel, antibiotic use, number of stools per day, examination of stool including frequency, amount, color, consistency, and presence of blood and mucus plays a key role in the diagnosis and care of gastroenteritis [39]. Viral gastroenteritis is of shorter duration than bacterial gastroenteritis and is associated with an increased risk of vomiting and dehydration compared with those without viral infection. The severity of dehydration is significantly higher in children infected with either astrovirus or rotaviruses group A [40].

Conventional methods for isolation of causative organisms: Isolation and identification of the causative agents such virus and bacteria is the gold standard diagnostic technique. Stool, vomit and diarrheal samples were taken for isolation of microorganisms. Samples were added into enrichment medium and transferred to bacteriological media including MacConkey agar, Xylose lysine deoxycholate agar, Bismuth sulfite agar, and Salmonella-Shigella agar, Simmon citrate agar, Manitol salt agar, Hecktoen enteric (HE) agar, Tryptic soya agar, Chrom agar, PALCAM listeria agar are used to detect E. coli O157:H7, Salmonella, Shigella, Aeromonas, Plesiomonas, Vibrio, Yersinia, Campylobacter species, Listeria monocytogenes and Clostridium difficile. Viruses were isolated by using SPF embryonated eggs and cell culture systems $[41,42]$.

Immunodiagnostic methods: Immunological assay are extensively utilized for the diagnosis of waterborne diseases, typically for pathogens that are difficult to isolate directly. The accuracy of any serological test is mainly dependent upon many factors including antigen and titer of antibodies in the serum. A number of assay such as agar gel precipitation test, agglutination tests, immune-electrophoresis, enzyme linked immunosorbant assay, neutralization tests, line immunoassay, complement fixation test and fluorescent antibody technique is used for diagnostic purposes $[41,43,44]$.

Recent diagnostic approaches: Molecular diagnostic tools play an emergent role in the diagnosis of bacterial, mycobacterial, and viral infections. In these tests, biological markers in the genome and amplification of nuclear material are used. These tests are highly specific and sensitive as compared to traditional diagnostics. PCR, RT-PCR $[45,46]$. Fluorescence in situ hybridization, loop-mediated isothermal amplification, microarray analysis and Q-PCR $[47,48]$ is used in molecular biological assays [49].

\section{Treatment of gastroenteritis}

Decades ago, homeopathic remedies were a major prescribed treatment to control gastroenteritis in many countries such as Japan, Germany, Pakistan, India, Bangladesh, Srilanka etc. Aconites, Aloe, Arsenicum album, Cinchona, Croton tiglium, Ipeca and Podophyllum are the homeopathic medicines currently used extensively for curing of gastroenteritis. These medicines have fewer side effects as compared to allopathic medicines. Medicinal plants also play a significant role in the preparation of affective therapeutic agents. These medicines significantly improve gastrointestinal motility by inducing gastrointestinal motor activity and exerting both stimulatory and inhibitory affects in human plasma [50,51]. Oral rehydration therapy (ORS) proved efficient results in children suffering from gastroenteritis and this therapy decreased the bowel movements and fluid loss and shortened the duration of illness. In gastroenteritis treatment, antimicrobials are not generally used. But in severe cases like fever and bloody diarrhea azithromycin, metronidazole or vancomycin are prescribed. Probiotics like Bifdobacterium bifidum and Lactobacillus acidophilus help repair and heal of intestinal mucosa $[52,53]$.

Vaccination is the only way to combat viral gastroenteritis, especially rotavirus gastroenteritis [54] associating this virus as the more significant hospital acquiring cause of gastroenteritis in children. Guidelines to minimize the severe gastroenteritis in children could, hence, be motivated best on inhibition of rotavirus infections. The primarily preventive measure against rotavirus is immunization [55]. Now days, two rotavirus vaccines are available i.e. (Box) monovalent rotavirus vaccine made by attenuating a highly antigenic strain of human G1P rotavirus and pentavalent vaccine (RV5) formed by reasserting of $P$ and $G$ antigens from human rotavirus origin and bovine rotavirus strain $(\mathrm{G} 1, \mathrm{G} 2, \mathrm{G} 3, \mathrm{G} 4$ and $\mathrm{P})[56,57]$. These vaccines produced up to fifty percent protection against rotavirus infections $[58,59]$.

\section{Control and prevention of gastroenteritis}

In developing countries like Pakistan, smoking was observed also a main cause of gastrointestinal infection. By avoiding this habit, risk of this illness can be minimized [4]. For control and prevention of pathogenic bacteria from spreading, food and water should be treated in such a way that there would be no or minimum chances of contamination [60]. Protection against infectivity and limitation of microbial growth harms can be offered by maintaining an antiseptic residual all over the water supply system. Water supply systems should be completely enclosed, and storage reservoirs and tanks should be strongly roofed with external drainage to prevent contamination. Programmers of pipe replacement, flushing, relining and maintaining positive pressure in the water supply system should be introduced. A more constant secondary disinfecting chemical such as chloramines 
instead of free chlorine should be used because chloramination has proved successful to control microbial multiplication. Chlorination is employed primarily for microbial disinfection. Traditionally chlorine dioxide was not commonly used for drinking water disinfection, but recently it has been used because of trihalomethane production coupled with chlorine disinfection. Emitted UV radiations by a low-pressure mercury lamp are used to inactivate bacteria and other microbes because it is biocidal between $180-320 \mathrm{~nm}$ of wavelength [61].

Clothes washing in the wells and ponds should be prohibited to avoid contamination of water. During waterborne outbreaks, pure water should be provided to the population to prevent further outbreaks. Wells used for drinking water should be protected and covered. Peoples should be educated for the safe use of wells and ponds to minimize the chances of water contamination and waterborne infections [62]. Persons having any waterborne illness should be treated properly using antibiotics for which these waterborne bacterial pathogens are susceptible. Their fecal samples should be cultured and examined regularly. Infected persons should be kept away or separate from uninfected persons in home, day care centers and hospitals to prevent further cases of illness. Potable filtered water should be provided to the infected and healthy peoples during outbreaks. Efforts for good personal hygiene education, proper sewage disposal, clean water supply and treatment should be introduced in developing countries [63]. When water supply systems are poorly managed, public health becomes risky. To minimize this risk management practices should be adopted to remove the option for satisfaction and work to prevent contamination water supply system [64].

\section{Conclusion}

Based on the literature cited here it can be concluded that gastroenteritis is one of the most horrible threat to human health throughout the world. This literature intended to increase awareness of waterborne pathogens as gastroenteritis and shed additional lights on its epidemiology including worldwide prevalence, possible host, causative agents, associated risk factors, clinical signs and symptoms, conventional as well as molecular diagnostic approaches and recent way of treatments and new methods in controlling these infectious agents causing gastroenteritis. In the future, we hope that this information would aid in identification and control more effectively with better results.

\section{References}

1. Friesema HM, Boer R, Duizer E, Kortbeek LM, Notermans DW, et al. (2012) Aetiology of Acute Gastroenteritis In Adults Requiring Hospitalization In The Netherlands. Epidemiol Infect 140: 1780-1786.

2. Alam MM, Khurshid A, Shaukat S, Rana MS, Sharif S, et al. (2015) Viral Etiologies of Acute Dehydrating Gastroenteritis in Pakistani Children: Confounding Role of Parechoviruses. Viruses 7: 378-393.

3. Mukherjee R, Halder D, Saha S, Shyamali R, Subhranshu C (2011) Five Pondcentred Outbreaks of Cholera in Villages of West Bengal, India: Evidence for Focused Interventions. J Health Popul Nutr 29: 421-428.

4. Valliani A, Ahmed B, Nanji K, Valliani S, Zulfigar B, et al. (2012) Use of Smokeless Tobacco amongst the Staff of Tertiary Care Hospitals in the Largest City of Pakistan. Asian Pac J Cancer Prev 13: 2315-7.

5. Grover M (2014) Role of gut pathogens in development of irritable bowel syndrome. Ind J Med Res 139: 11-18.

6. Porter CK, Gormley R, Tribble DR, Cash BD, Riddle MS (2011) The Incidence and Gastrointestinal Infectious Risk of Functional Gastrointestinal Disorders in a Healthy US Adult Population. Am J Gastroenterol 106: 130-138.

7. Das SK, Chisti MJ, Afrad MH, Malek MA, Ahmed S, et al. (2014) Gastroenteritis due to typhoidal Salmonella: a decade of observation at an urban and a rural diarrheal disease hospital in Bangladesh. BMC Infect Dis 14: 435-442.
8. Fitzenberger J, Uphoff $\mathrm{H}$, Gawrich S, Hauri AM (2010) Urban-rural differences of age-and species-specific campylobacteriosis incidene, Hesse, Germany, July 2005-June 2006. Euro Surveill 15: 19693-19700.

9. Rahal EA, Kazzi N, Nassarand FJ, Matar GM (2012) Escherichia coli O157:H7clinical aspects and novel treatment approaches. Cel infect microbial 2: 1-7.

10. Iwamoto M, Ayers T, Mahon BE, Swerdlow DL (2010) Epidemiology of SeafoodAssociated Infections in the United States. Clin Microbiol Rev 23: 399-411.

11. Wikswo ME, Hall AJ (2012) Outbreaks of acute gastroenteritis transmitted by person-to-person contact--United States, 2009-2010. MMWR Surveill Summ 61: 1-12.

12. Osborne CM, Montano AC, Robinson CC, Schultz-Cherry C, Dominguez SR (2015) Viral Gastroenteritis in Children in Colorado 2006-2009. J Med Viro 87: 931-939.

13. Khanna N, Goldenberger D, Graber P, Battegay M, Widmer AF (2003) Gastroenteritis outbreak with norovirus in a Swiss university hospital with a newly identified virus strain. J Hosp Infect 55: 131-136.

14. Barret AS, Silva NJ, Ambert-Balay K, Delmas G, Bone A, et al. (2014) Surveillance for outbreaks of gastroenteritis in elderly long-term care facilities in France, November 2010 to May 2012. Euro surveill 19: 1-8.

15. So CW, Kim DS, Yu ST, Cho JH, Kim JD (2013) Acute viral gastroenteritis in children hospitalized in Iksan, Korea during December 2010-June2011. Korean J Pediatr 56: 383-388.

16. Fertleman C, Bentley G (2002) Factors Predisposing Infants to Gastroenteritis Among Poor, Urban, Filipino Families. Internet J Pediatr Neonatol 3: 1-7.

17. Hung T, Wang C, Fang Z, Chou Z, Chang X (1984) Water-borne outbreak of rotavirus diarrhea in adults in China caused by novel rotavirus. Lancet 1 : $1139-42$.

18. Fang ZY, Ye Q, Ho MS, Dong H, Qing S, et al. (1989) Investigation of an outbreak of adult diarrhea rotavirus in China. J Infect Dis 160: 948-53.

19. Riaz MM, Patel MJ, Khan MS, Anwar MA, Tariq M, et al. (2012) Clinical characteristics and predictors of positive stool culture in adult patients with acute gastroenteritis. J Pak Med Assoc 62: 20-24.

20. Chitambar SD, Lahon A, Tatte VS, Maniya NH, Tambe GU (2011) Occurrence of Group B Rotavirus Infections in the Outbreaks of Acute Gastroenteritis from Western India. Indian J Med Res 134: 399-400.

21. Rahman M, Nahar S, Afrad, MH, Faruque ASG, Azim T (2013) Norovirus Variant GII.4/Sydney/2012, Bangladesh. Emer Infect Dis 19: 1347-1348.

22. Emamian MH, Mohammad MG (2013) An Outbreak of Gastroenteritis Among Iranian Pilgrims of Hajj during 2011. Iran Red Crescent Med J 15: 317-319.

23. Tayeb HT, Balkhy HH, Aljuhani SM, Elbanyan E, Alalola S, et al. (2011) Increased prevalence of rotavirus among children associated gastroenteritis in Riyadh Saudi Arabia. Virol J 8: 548

24. Khali M, Azhar E, Kao M, Al-Kaiedi N, Alhani H, et al. (2015) Gastroenteritis attributable to rotavirus in hospitalized Saudi Arabian children in the period 2007-2008. Clin Epidemiol 7: 129-137.

25. Kirkwood CD, Streitberg R (2008) Calicivirus shedding in children after recovery from diarrhoeal disease. J Clin Virol 43: 346-348.

26. Leslie T, Whitehouse CA, Yingst S, Baldwin C, Kakar F, et al. (2011) Outbreak of Gastroenteritis Caused By Yersinia Pestis in Afghanistan. Epidemiol Infect 139: 728-735.

27. Westerman LJ, Schipper MEI, Stel HV, Bonten MJM, Kusters JG (2013) Appendiceal spirochaetosis in children. Gut pathog 5: 40-51.

28. Galindo CL, Rosenzweig JA, Kirtley ML, Chopra AK (2011) Pathogenesis of $Y$. enterocolitica and Y. pseudotuberculosis in Human Yersiniosis. J Pathog 10: $1-16$.

29. Vega E, Vinjé J (2011) Novel GII. 12 norovirus strain, United States, 2009 2010. Emerg Infect Dis 17: 1516-1518.

30. Solanke V, Pai C, Surase SG (2011) Aeromonas Hydrophila causing Acute Gastroenteritis in A child. Bombay Hosp J 53: 487-489.

31. Sung KJ, Kim JY, Lee YJ, Hwang EH, Park JH (2014) High Incidence of Staphylococcus aureus and Norovirus Gastroenteritis in Infancy: A SingleCenter, 1-Year Experience. Pediatr Gastroenterol Hepatol Nutr 17: 140-146. 
Citation: Siddique F, Iqbal A, Sabir H, Manzoor M, Hussain I, et al. (2015) Eco-Epidemiology and Control of Waterborne Gastroenteritis: A Review. J Food Process Technol 6: 477. doi:10.4172/2157-7110.1000477

32. Karve S, Krishnarajah G, Korsnes JS, Cassidy A, Candrilli SD (2014) Burden of acute gastroenteritis, norovirus and rotavirus in a managed care population. Hum Vacc Immunother 10: 1544-1556.

33. Ruben S, Alseda M, Godoy P, Sanz M, Bartolomé R, et al. (2014) Person-toperson transmission of norovirus resulting in an outbreak of acute gastroenteritis at a summer camp. Eur J Gastroen Hepat 26: 1160-1166.

34. Susanne E, Daleno C, Scala A, Senatore L, Ascolese B, et al. (2014) Detection of norovirus in respiratory secretions in children with respiratory tract infection. Pediatr Infect Dis J 33: 314-316.

35. Devrajani BR, Shah SZA, Shaikh S, Shaikh S, Essa S (2009) Hypocalcemia in Acute Gastroenteritis (A Case-Control Study at Department of Internal Medicine). World Appl Sci J 7: 777-780.

36. Mozhgani SHR, Samarbaf-Zadeh AR, Makvandi M, Shamsi-Zadeh A Parsanahad $\mathrm{M}$, et al. (2011) Relative frequency of astrovirus in children suffering from gastroenteritis referred to Aboozar hospital, Ahvaz. Jundishapur J Microbiol 4: S67-S70.

37. Mladenova Z, Steyer A, Steyer AF, Ganesh B, Petrov P, et al. (2015) Aetiology of Acute Paediatric gastroenteritis in Bulgaria during summer months: prevalence of viral infections. J Med Microbiol 64: 272-82.

38. Enserink R, Wijngaard VC, Bruijning-Verhagen P, Mughini-Gras L, Duizer E, et al. (2015) Gastroenteritis Attributable to 16 Enteropathogens in Children Attending Day Care: Significant Effects of Rotavirus, Norovirus, Astrovirus, Cryptosporidium and Giardia. Pediatr Infect Dis J 34: 5-10.

39. Elliott EJ (2007) Acute gastroenteritis in children. Br Med J 334: 35-40.

40. Ciccarelli S, Stolfi I, Caramia G (2013) Management strategies in the treatment of neonatal and pediatric gastroenteritis. Infect Drug Resist 6: 133-161.

41. Jansen A, Stark K, Kunke J, Schreier E, Ignatius R, et al. (2008) Aetiology of community-acquired, acute gastroenteritis in hospitalised adults: a prospective cohort study. BMC Infect Dis 8: 143-149.

42. Hassan C, Repici A, Sharma P, Correale L, Zullo A, et al. (2015) Efficacy and safety of endoscopic resection of large colorectal polyps: a systematic review and meta-analysis. Gut gutjnl 64: 5-10

43. Platts-Mills JA, Liu J, Houpt ER (2013) New concepts in diagnostics for infectious diarrhea. Mucosal Immunol 6: 876-885.

44. Humphries RM, Linscott AJ (2015) Laboratory Diagnosis of Bacterial Gastroenteritis. Clin microbiol rev 28: 3-31.

45. Rezaei M, Sohrabi A, Edalat R, Siadat SD, Gomari H, et al. (2012) Molecular Epidemiology of Acute Gastroenteritis Caused by subgenus $F(40,41)$ Enteric Adenoviruses in Inpatient Children. Lab Med 43: 10-15.

46. Ghosh R, Uppal B, Aggarwal P, Chakravarti A, Jha AK, et al. (2014) A comparative study of conventional and molecular techniques in diagnosis of campylobacter gastroenteritis in children. Ann Clin Lab Sci 44: 42-48.

47. Montes M, Iturriza-Gómara M (2008) Molecular methods for the diagnosis of acute viral gastroenteritis. Enferm Infecc Microbiol Clin 9: 81-5.

48. Rodríguez-Lázaro D, Cook N, Sellwood J, Nasser A, Ruggeri FM, et al. (2012) Virus hazards from food, water and other contaminated environments. FEMS Microbiol Rev 36: 786-814.

49. Apaza S, Espetia S, Gilman RH, Montenegro S, Pineda S, et al. (2012) Detection and Genogrouping of Noroviruses from Children's Stools By Taqman One-step RT-PCR. J Vis Exp 65: 3232-3236

50. Shan T, Lou J, Gao S, Zhou Y, Sun W, Luo C, et al. (2012) Antibacterial activity of the endophytic fungi from a traditional Chinese herb Paris polyphylla var. chinensis. Afr J Microbiol Res 6: 3440-3446.

51. Uehara S, Ogawa K, Arimitsu J, Okuyama H (2015) Ninjinto (Ginseng Decoction), a Traditional Japanese Herbal Medicine, Improves Gastrointestinal Symptoms and Immune Competence in Patients with Chronic Intestinal Failure. J Evid Based Complement Altern Med 12: 5-12.
52. Guandalini S (2008) Probiotics for children with diarrhea: an update. J Clin Gastroenterol 2: 53-7.

53. Szajewska H, Guarino A, Hojsak I, Indrio F, Kolacek S, et al. (2014) Use of probiotics for management of acute gastroenteritis: a position paper by the ESPGHAN Working Group for Probiotics and Prebiotics. J Pediatr Gastroenterol Nutr 58: $531-9$

54. Podkolzin AT, Fenske EB, Abramycheva NY, Shipulin GA, Sagalova OI, et al. (2009) Hospital-based surveillance of rotavirus and other viral agents of diarrhea in children and adults in Russia, 2005-2007. J Infect Dis 200: S228233.

55. Zomer TP, Duynhoven YTV, Mangen MJ, Maas VDNA, Vennema $\mathrm{H}$, et al. (2008) Assessing the introduction of universal rotavirus vaccination in the Netherlands. Vaccine 26: 3757-3764.

56. Vesikari T, Matson DO, Dennehy P, Damme VP, Santosham M, et al. (2006) Safety and efficacy of a pentavalent human-bovine (WC3) reassortant rotavirus vaccine. N Engl J Med 354: 23-33.

57. Lybol C, Thomas CM, Blanken EA, Sweep FC, Verheijen RH, et al (2013) Comparing cisplatin-based combination chemotherapy with EMA/CO chemotherapy for the treatment of high risk gestational trophoblastic neoplasia. Eur J Cancer 49: 860-867.

58. Madhi SA, Cunliffe NA, Steele D, Witte D, Kirsten M, et al. (2010) Effect of human rotavirus vaccine on severe diarrhea in African infants. $\mathrm{N}$ Engl $\mathrm{J} \mathrm{Med}$ 362: $289-98$

59. Muhsen K, Chodick G, Goren S, Shalev V, Cohen D (2010) The uptake of rotavirus vaccine and its effectiveness in preventing acute gastroenteritis in the community. Vaccine 29: 91-94.

60. Zhong C, Li NK, Wang BC, Bi JW (2012) Sodium intake, salt taste and gastric cancer risk according to Helicobacter pylori infection, smoking, histological type and tumor site in China. Asian Pac J Cancer Prev 13: 2481-4.

61. Braeye T, Schrijver DEK, Wollants E, Ranst MV, Verhaegen J (2015) A large community outbreak of gastroenteritis associated with consumption of drinking water contaminated by river water, Belgium, 2010. Epidemiol Infect 143: 711-719.

62. Das A, Manickam P, Hutin Y, Pal BB, Chhotray GP (2009) An Outbreak of Cholera Associated with an Unprotected Well in Parbatia, Orissa, Eastern India. J Health Popul Nutr 27: 646-651.

63. Kamel AH, Ali MA, El-Nady HG, Aho S, Pothier P, et al. (2010) Evidence of the co-circulation of enteric viruses in sewage and in the population of Greater Cairo. J app microbiol 108: 1620-1629.

64. Kot M, Castleden H, Gagnon GA (2015) The human dimension of water safety plans: a critical review of literature and information gaps. Environ Rev 23: 24-29. 